\title{
Aid in Afghanistan: Limitations and Possibilities
}

\author{
by Anders Fänge
}

When Louis Dupree last Christmas Eve asked me if I would like to contribute an article about Afghanistan to a forthcoming issue of Refuge, I was honoured and accepted the offer willingly. Louis suggested the title "ACBAR and SWABAC: a Unique Experiment in NGO co-ordination".

Last Christmas was a time of hopes and expectations. The Soviets were just about to complete their withdrawal from Afghanistan, and most of us believed that the war would soon be over. TV crews and journalists thronged all over Peshawar, preparing themselves for the big scoop, when the last Soviets would leave Kabul hanging from the last helicopter. The international aid apparatus was gearing up its heavy machinery, although "Operation Salaam", the UN body which had been established seven months earlier with the purpose of coordinating aid to Afghanistan, had difficulties in getting its feet planted in the field. The Agency Co-ordinating Body for Afghan Relief (ACBAR), an umbrella organization in Peshawar encompassing over 50 non-governmental organizations (NGOs), and the Southwestern Afghanistan and Baluchistan Agency for Co-ordination (SWABAC), a sister organization with a membership of 15 NGOs based in Quetta, had been created with the purpose of co-ordinating the work of the NGOs. They had also problems in getting their practical act together. Nevertheless, the air was filled with enthusiasm and a kind of pioneering spirit: meetings succeeded meetings and everyone in the aid community was discussing problems related to the anticipated repatriation of the refugees and the rehabilitation of the country. We were all in for a very big job and the eyes of the world were upon us.

However, since last Christmas a lot of things have happened, others not. To mention a few; the Red Army did leave Afghanistan, but the war did not cease. Instead of peace came the battle for Jelalabad, and instead of repatriation a multitude of new refugees poured over the border. The TV crews and the journalists disappeared, but the aid workers are still here. They continue their work; at a slightly slower pace, with a little less enthusiasm and, perhaps, a more sober view towards the future. Nevertheless, it was a period of learning. The UN and its agencies learned a little about the peculiarities of Afghanistan and the NGOs learned how to do the paper work in order to get funds from the UN. We also learned that it is very difficult to co-ordinate 70-odd NGOs and that ACBAR and SWABAC were not quite as unique as we had believed them to be, that other efforts of co-ordination between NGOs had been carried out elsewhere.

So, when the time finally came to write this article, I felt that the title which Louis had suggested was somewhat out of date. Besides, the only thing which is really unique in this specific context of aid is Afghanistan itself, and that any effort aimed to understand the problems of the NGOs and the rest of the aid community in Afghanistan has to begin with Afghan society itself and, especially, the profound change in the political conditions which started with the Communist coup d'état in April 1978. That is why the title was changed, and I am quite certain that Louis would have agreed with the change.

\section{The Limitations}

We always tend to look upon the world through glasses coloured by our own political and cultural experiences. To an extent it is unavoidable, but the problem increases undoubtedly the higher up in the bureaucracies we get. The closer to heaven, the less understanding of what actually is going on, of the problems and the specific conditions in a certain environments. In this regard, Afghanistan is no unique case. The misconceptions are many. One, which concerns aid, is the belief that it is somehow possible to execute conventional, large-scale and massive aid operations in Afghanistan. That is not the case. However, this is not the same thing as to say that it is impossible to organize humanitarian aid efforts at all. Aid operations are carried out right at this moment and it has been done by NGOs since the beginning of the war. The crucial point is to understand both the limitations and the possibilities of aid in the extremely politicized environment of Afghanistan.

\section{The War}

To start with the most obvious, the war not only created the need for a large international aid effort through the immense destruction it has brought upon the land and its people., but it represents, at the same time, one of the most fundamental obstacles to any such large-scale operation. War is an anathema to humanism . In any armed conflict, especially when it has been as uncompromising and as long as in Afghanistan, there is a strong tendency among the contending parties to give priority to their own political interests at the expense of the interests of the common man.

Consequently, since the war has divided Afghanistan into two antagonistic parts, there are two ways to get aid into the country, and both of them are limited. One is to work through Kabul, from where it is possible to reach those living in the cities and in the immediate vicinities of the cities. The other is to organize aid from Pakistan in co-operation with the resistance, which dominates the main part of the rural areas.

\section{A Mosaic of Powers}

The second essential obstacle arises from the far-reaching changes in the sociopolitical conditions which has taken place during the war. Its main characteristic is the destruction of state authority and the subsequent fragmentation of political power. 
Historically, Afghanistan was characterized by a balance between the state and more or less broad power groups based on traditional concepts. The popular uprising which followed the Communist coup d'état in 1978, which accelerated after the Soviet invasion, signified the total collapse of state control and its replacement by a multitude of local units which later coalesced into a few loosely united regional power groups comprised of mujahidin (resistance fighters).

The political parties of the resistance have never, in spite of several efforts, been able to fill the gap and act as a central authority for the areas which are under their control. They have been too preoccupied with factional quarrels and too dependent on foreign powers, especially Pakistan. With one exception, they are too badly organized to provide an alternative, and this is also true of the "interim government" which was established in the beginning of 1989 .

Newly-arrived observers mistakenly equate the political parties based in Pakistan with the resistance inside Afghanistan. They forget that the political party is an almost totally new concept in Afghan political life, at the most not more than 25 years old. There are certainly variations between the parties; some are relatively more efficient, some less, but in general they do not function like centralized political parties in the West. They exercise a limited control of the resistance inside the country. The local or regional commanders are, in the end, their own masters, who independently take care of their own matters and play their own political games. As a result, most party leaders do not even try to direct them.

There are all sorts of commanders inside Afghanistan: traditional and modern; fanatics and open-minded; educated and illiterates; corrupt and honest; smart and stupid. Some organize their people to carry out reconstruction work, establish clinics and schools, clean irrigation channels, provide seed and fertilizer. There are groups loosely linked together through ethnic group, clan or tribal loyalties, while others function, quite simply, within their own extended family. Then, there are commanders who, in co-operation with other commanders and traditional power groups, rule over large areas in which they have established functioning administrative systems with thousands of disciplined, well-organized mujahidin. Most commanders are against the Kabul regime, but a few leap back and forth between the mujahidin and the "government".

Finally, there are "Peshawar commanders", an honorary title given to former commanders who have not trampled Afghan soil for the last five years and who often make a living from cheating aid agencies in Peshawar.

Undoubtedly, the commanders are the strongest and at the same time the most unpredictable political force in Afghanistan today. They exemplify the fact that the Afghan resistance is both united under the banner of Islam, but also fragmented between ethnic, tribal, religious and political allegiances. They are the product of the war and their power increased throughout the war. On the other hand, they will not cease to exist when peace comes. For some of them, the future might bring influential positions in the establishment which will arise out of the war. A few will revert to banditism, but, hopefully, the great majority will continue to be responsible Afghan citizens, working with traditional local groups in the villages. Gradually, local groups will have to cope with an emerging central authority, provided that such an authority can obtain the formal approval of the local groups. This, however, will not necessarily mean that the commanders will hand over their weapons, dissolve their groups and happily return to the life they enjoyed before the war. They have been used to running their own affairs for ten years, and they will not voluntarily give up these prerogatives.

Thus, the second conclusion is that the fragmentation of political power significantly limits the possibility of carrying out conventional large-scale aid operations. In concrete terms this means that the aid community does not have one counterpart but, rather, hundreds of them. Moreover, this situation will probably continue for the foreseeable future, even if there is a government established which has even a nominal acceptance of the Afghan people.

\section{Destruction and the Lack of Human Resources}

After ten years of war, Afghanistan and the Afghan people have suffered enormously. Figures like five million refugees, more than a million dead, and an agricultural production which in 1987 had decreased to $52 \%$ compared to 1978 , not counting abandoned farms, give strong evidence of a total war effort largely directed against the civilian population. There are no statistics available on infrastructure, but reports, as well as the abovementioned figures, indicate widespread and serious devastation.

The brain drain has reached critical proportions. Huge numbers of Afghan intellectuals have been imprisoned, tortured, killed or just simply vanished. Thousands have sought refuge in Saudi Arabia, the Gulf States and in the West, and still others have been preoccupied with military or political tasks. Refugee students trained in the educational system of the Kabul regime do not meet elementary standards. Aid agencies, therefore, have great difficultiy in finding trained Afghans for positions in administration or any kind of project work, even in the current situation of relatively low levels of aid.

The third conclusion is, consequently, that the destroyed infrastructure and the lack of human resources severely restrict the handling of big amounts of relief goods as well as the now much needed build up of administrative and project implementation capacity.

\section{The Possibilities}

Limitations and difficulties do not exclude possibilities. International aid in wartime Afghanistan has been carried out mainly through NGO crossborder operations from Pakistan. Kabul was not considered as an alternative because of political as well as practical considerations. NGO work has gone through several stages, but for the purpose of this article it can be divided into two periods; from the beginning of the eighties until the summer of 1988 , and from that time onwards.

\section{0-1988}

Crossborder assistance started just after the Soviet invasion with the French Doctors being the first on the scene. They were closely followed by Austrians, other French organizations, Swedes, Norwegians, the British and Dutch. NGOs from different Islamic countries were also involved early, and when the US Government in 1985 established a humani- 
tarian aid programme in Afghanistan, American NGOs followed.

With a few exceptions, the organizations were new and politically-oriented in the sense that they took an open stand against the Soviet invasion. Many had no former experience in relief, not to mention development, which meant that programmes during the first years were rather unsophisticated. On the other hand, thanks to their freshness there was never any shortage of ideas. Successful solutions were often unconventional and not hampered by routine opinions, nor by an excessive load of administrative work. Their strength was engagement, unconventional methods and a pragmatic downto-earth approach. Their weakness lay generally in poor administration, a lack of technical capacity and an exaggerated feeling of their own importance, resulting in co-ordination difficulties. However, it would be unfair to attribute the last-mentioned trait only to NGOs.

To organize programmes for humanitarian assistance in a crossborder situation involves a whole range of problems usually not found in more normal situations. The fact of being stationed in one country while carrying out aid in another, particularly another ravaged by war, means that most processes related to project implementation are much more complex and cumbersome. Communication is not a question of hours, but of days and even weeks. You just do not jump into your car, drive out to the project, knock at the door and spend a few hours with the field personnel. The situation is further complicated by the fact that the Pakistani government has never officially acknowledged the existence of crossborder aid operations.

A specific difficulty is the absence of a centralized counterpart. NGOs have tried to solve this problem by establishing, whenever possible, direct links with local and regional authorities inside Afghanistan, i.e., in most cases the commanders. Most often it has been done with the co-operation of the political parties in the resistance, though sometimes dissatisfaction rises over the fact that the aid is not controlled by them.

A decentralized approach has been the most successful. Because conventional planning has not been conducted except in a very flexible way, it has been possible to take fast decisions in the rapidly changing environment so as to seize every opportunity as it shows up. It goes without saying that it has been a long process of trial and error which, among other things, has resulted in an accumulated and profound knowledge about conditions in wartime Afghanistan.

Despite weaknesses, NGOs proved during 1980-1988 that it is possible to manage relief in the rural areas of Afghanistan. Their primary motivating force was a commitment to the Afghan people.

\section{The Arrival of the UN}

Since the Kabul regime occupied the chair of Afghanistan in the UN General Assembly, the UN initially considered itself unable to support aid operations in areas controlled by the resistance. This changed when the Geneva Accords stipulated the withdrawal of Soviet troops. Shortly after the Accords were signed in April 1988 the UN Secretary-General appointed Prince Sadruddin Agha Khan as the Co-ordinator of all UN assistance to Afghanistan, and in June Prince Sadruddin launched an appeal for Afghanistan in which the figure $\$ 1,116$ billion was mentioned as needed for aid during an initial period of 18 months.

The NGOs in Peshawar were skeptical concerning the size of the amount; voicing reservations about the lack of an implementation capacity. Nonetheless, they were also influenced by the possibility of a Soviet withdrawal and in August 1988 ACBAR was formed in Peshawar by roughly 40 NGOs working either in Afghanistan or among the refugees in Pakistan. Soon thereafter SWABAC, a sister organization with about 15 NGOs, came into being in Quetta. The main purpose of both organizations was to co-ordinate NGOs for the purposes of preparing for an eventual repatriation of the refugees and a reconstruction of Afghanistan.

For the NGOs working crossborder, the co-operation with the UN and its different agencies was a new experience, but in general, cooperation has been above expectations, although more or less wellfounded tensions temporarily occur.

\section{A Changed Situation in Afghanistan}

Radical changes have occurred in Afghan rural areas. Huge areas, which during the nine years of Soviet occupation had been subject to armed conflict, are pacified. The terror of war falls now upon the population in the cities, while in the countryside life goes increasingly back to normal. From the Peshawar horizon the most noticeable change, perhaps, has to do with the conditions in communications. One does not travel or transport goods with horses or other pack animals any more. One goes with trucks or pick-ups, and places, which it took weeks to reach, are now reached in a day or two.

The result is that Afghan rural areas, to an extent no one could dream of only a year ago, have opened up for travel, trade and aid operations. The NGOs, with support from the UN, can now offer more assistance in the rehabilitation of agriculture, repair of irrigation systems, roads, buildings and so on. New and certified wheat seed are brought, veterinary as well as plant protection services are offered. Efforts to establish health care systems have become easier. A successful expansion of the aid work has taken place, which makes it most alarming to hear signals from some Western governments about holding back on funding. It is difficult to predict the future, but we know one thing for certain: the Afghan people will be in great need of help for the foreseeable future. The fact that the war continues is not an argument against, but rather in favour of, that presumption.

\section{A Model for the Future}

So far, the main channel for the UNagencies into Afghanistan has been support for projects run by NGOs. There is a need for refining the process and clearly defining roles. As long as there is no effective central authority in Afghanistan, it is consistent that the NGOs, with their more pragmatic approach, relatively larger flexibility and greater experience of field conditions, take the main burden of actual project implementation. It is also consistent that the UN takes a more forceful part, not only in issues like supplies, technical and financial support, but in co-ordination, monitoring and evaluation. This will not only push NGOs to correct their mistakes and upgrade their performances, it wil $l$ also teach UN personnel about conditions in the field.

The conclusion is simple; the UN needs the NGOs and vice versa. But, most importantly, the people of Afghanistan need them both. 